\section{Author's Reply}

\section{Dear Editor,}

With reference to the letter written by $\mathrm{Wg}$ Cdr PVPD Singh regarding the article [1]. Para-wise reply to the points highlighted and supplemental pertinent data are as follows

Point No. 1 - The figure quoted is for the adult population of America and Britain as quoted by Prakash [2] (reference 7 in my article). The oversight is regretted.

Point No. 2 . The authors were not aware of the paper by Malhotra [3]. No report of uases of cholclithiasis from north cast India could be delected on Med line search.

Points No. 3, 4 \& 5-Selection of controls : The controls were selected from serving male adults of the lak medical services hailing from Tamil Nadu and Kerala. They were selected since these areas have a relatively lower incidence of cholelithasis as compared to other areas of India [4]. They were matehed for build and nourishment. Selection wats designed to remove bias towards hereditary, local or dictary factors. The suggestion of including the local populace as a second group of control is meaningful and should be included in future studies.

Point No. 6-Bile Acid Assays : "he sludy would have been more mean ing ful if bile acid assays of serum and bile could have been carried out. However analysis by IIPI,C could not be carried out due to lack of equipment, stand ards and solvents of appropriate grade. Manual methods for assays of hile acids [5], di- and tri-hydroxy bile acid ratios were tried $|6|$, however they are eumbersome and difficult to perfortm and didn ${ }^{\top} \mathrm{t}$ give reproducible results in my hands.

Point No. 7 - Concentration function of diseased gall bladder : Diseased gall bladder in chronic cholecystitis have been showr experimentally to be associnted with a decrease in the bile acid pool size [7,8]. Cholelithiatic gall bladders in the present study have been shown to have histologic changes of cholecystitis. This may be one of the most important factors which alter the cholesterol, phospholipid, bile acid ratios resulting in precipitation of bile. A decreased bile salt pool size is almost certainly aeliologically linked to the increased incidence of gall stones as seen in palients with ileal resection and Crohu's disease of the distal ileum [8].

Point No. 8 - Bilirubin, cholesterol, LCAT, PI. : Bilirubin, Cholesterol, I.CAT, PL (phospholipid phosphorus) and ALP ware the parameters assayed in samples of bile from the hepatic duct and gall bladder bile. While bilirubin, cholesterol, LCAT show almost four-fold increase PL shows a marked increase of 7.6 times. This suggests that there is either an active process of secretion of phospholipid into the gall bladder or a more likely possibility of grcater reabsorption of bilirubin and cholesterol from the intlamed gall bladder wall as compared to phos- pholipid. Further studies are warranted on this aspect especially in the Indian context.

Point No. 9 - Phospholipid levels: Phospholipid levels as determined by the mothod of Connerty at al [9] are 25 times the serum phospholipid phosphorus. The values as determined by us, i.e. $63.75 \mathrm{mg} / \mathrm{dL}$ and $493.75 \mathrm{mg} / \mathrm{dL}$ for hepatic and gall bladder bile differ from those described by Wani et al, which were $815 \mathrm{mg} / \mathrm{dL}$ and $1723 \mathrm{mg} / \mathrm{dL}$ respectively [10]. Ramchandran el al [11] found a phospholipid level of $73 \mathrm{mg} / \mathrm{dL}$. in gall bladder bile. Regional variations in dict and nutrition are the probable cause of these wide ranging values. Ihis underscores the importance of a national study asing standardized nethodology to evaluate the actiopathogenesis of chold lithasis in hidia.

Points No. 10 \& 12 - Liver discaso or Ginl bladter disease? Esterification of cholesterol is dircty propor. tional to the CEA atuvity of the serum. l sethin cholesterol Acyl T'manslerase (LCAT) activity of serum of bile represents the cholesterol esterifying activity (CLA) wherein cholesterol is esteriticd by the enzymatic transfer of a fatly acid from the beta position of lecithin 10 cholestcrol. The LCAI ativity in the present study was seen to be markedly lower in the patients as compared to the controls. In cholelithiasis LCAT Jevels have betn shown to be lowered $[11,12]$ and this has been suggested to be a marker for choleliothiasis as well as hepatic discases [13]. Thus, at least in cholelithiasis, it is not judicious to say that gall bladder disease and liver diseases have nothing in common.

Another interesting fact which was not brought out in the paper was that chewing of raw fermented betel nut, called 'Tamul' in the local dialect, was a common habit irrespective of age and scx. Eighty seven percent of the patients were found to be regular users. The active ingredient "arecolinc" is a cholinomimetic natural alkaloid. It acts at the muscarinic and nicotinic receptors and stimulates smooth muscles of the intestinal tract [14]. So a possible role of arecoline in altering gall bladder contracLion and bile stasis cannot be ruled out. Hepatocyte injury (excess arecoline induced?) may also lead to subliminal rise in hepatic enzyme levels as seen in this study. This needs further research in the form of animal experiments and human sudies.

Point No. 11 - CBD Stotes: The cases included did not have evidence of choledocholithiasis. The material and methods clcarly mention that the 78 consccutive patients of cholelithiasis were subjects of the study [1].

Point No. 13 - Conclusions: 'the pointers for lithogenicity in the present study are raised serum cholesterol, reversed lecithin cholesterol ratio and lowered LCAT activity, as compared to their healthy counterparts from the relatively nonlithogenic arcas of the country. 
The a:' lor thanks Wg Cdr PVPD Singh for the keen interest shuwn and the critical review of the article. I lis letter has enabled us to claborate various points. It has also assisted in improved presentation of the various critical points in the pathogenesis of cholelithiasis in this remote area of the country for which published data is scanty. The experience derived could be used to improve future studies.

\section{REFERENCES}

1. Menon PK, Mahapatra S. Study of serutm and bile from patients of cholelithias is in North Eastern India. Modical Journal Armed Forces India 1995: $51: 9-12$.

2. Prakash $\Lambda$. Chronic cholecystitis and cholelithiasis in lndia. Itıtemational Surgery 1968:49:79-85.

3. Malhotra SL. Epidemiological study of cholelithiasis anong rail road workers in India with special reference to causation. Gut 1968;9:290-5.

4. Krishnam $A N$, Marayanan $K$, Kapur BML. Regional variation in lithogenicity of bile in Indian patients. Ind I Surg $1984 ; 46: 298-304$.

5. Irwin JL, Johnston CG, Kapola J. A photometric method for determination of cholates in bile and blood. $J$ Biol Chem 153 : $439-57$.

6. Carey JB. The sermu trihydroxy-dihydroxy bile acid ratio in liver and biliary tract disease. J Clin Inyest 1958; 37 :
1494-503.

7. Vlaheevic ZR, Bell CC, Buhle I, Farrar II', Swell L. Diminished bilc ació pool size in patients with gall stones. Gastroenternlogy $1970: 59: 165-9$

8. Roslyn .J, DenBesten L. Thompson JE, Cohen K. Chronic cholelilhasis and decreased bile salt ponl size : cause or effect? American J Surg 1980; 139: 119-23.

9. Connerty HV, Briggs AR, Eaton El J J. Serum phosphofipid estimation. Clin Chen 196!:37:580-7.

10. Wani MA, Kariholu Pl. Misgar MS, Weni MY, Khan M. Phospholipid and cholesterol estimation in hepatic duct and gall blatder bile in palients of cholelithiasis with functioning gall bladder in Kashmir. Ind J Surg 1986:48:346-9

11. Ramachandran K. Pushpalata M. Varkey $L_{2}$ Raveendranath $\mathrm{KK}$. Balasaraswathi KK. Biochemical assessment of cholclithiasis. J Asso Physicians India 1992; $40 ; 622-3$.

12. Swt $A W$, Griffin TFR, Reversed serum lecilhin : cholesterof ratios in relation to gall stone formation as a possible aid to Diagnosis. Br. I Clin Pract 1973; 27 : 87-90.

13. Joncs DP, Sosu FR, Shartsis J, Shah PT, Skromak E, Beher Wr. Serum clolesterol esterfying and cholesterol ester hydrolyzing activities in liver diseases. Relationships to cholestcrol, Bilirubin and bilc salt concentrations. J Clin Invest $1971 ; 50: 259-65$.

14. 'Iaylor P. Cholinergic agonists. In : Goodman Gilman's l' lie phasmacological basis of Therapeutics. 7th ed. New York, McMillan 100-9.

\section{DIVING AT HIGH ALTITUDE. PRESSURE MEDICINE - A NEW DISCIPLINE ?}

Dear Editor,

The lack of authoritative Indian research on high alitude ilinesses has been lamented in relation to the dependence on Western litcrature in a recent editorial. The authors have acknowledged past contributions in this field by scrvice medical officers and it is heartening to sec renewed directions by Indian research workers after many decades [1].

We wish to place on record our expcrience with Indian Navy divers in conducting in 1988 the worlds highest altitude scuba dives at Pangong Tso in Ladakh at an altitude of 14,200 feet. The experiences were published in a leading international joumal in the field of Diving Modicine [2]. This was acknowledged as being "Outstanding" by the Science Digest USA and is now used as a gudeline rot those venturing into the realm of high altitude, hyperbaric, diving and adventure nedicine. The limca $300 \mathrm{k}$ of Records also documents this dive [3].

Divers of the Indian Navy performed "no decompression" dives to a maximum of 140 feet sea water $(42.6 \mathrm{~m}$ of sea water) equivalent ocean depth at a maximum altitude o[ 14,200 fee $(4328 \mathrm{~m}$ ) and minimum water temperature of $2^{\circ} \mathrm{C}$. A total of 100 dives were perfomed at altiudes ranging from 7000 to 14,200 feet $(2134$ to 4,328 m). P'rior to this the highest socumented dive was that at 12500 fect (3810 m) in 1968 in Lake Titicaca by Jacques Cousleau. Subsequently in 1989 it British group conducted diving in the Nepali llimalayas al a maximum altitude of 16000 fect (4877 m) in Donag Tsho and to al maximum depth of 98 feet of sea water (29.3 $\mathrm{m}$ of fresh water) [4]

Diving at extreme altitudes in remote areas has the fascination of adventure in addition to the thrill of diving in unknown waters. Sufficient documented dives have not been carried out to recommend standard procedures. Also equipment used is untested at these altitudes. Apart from the physiological adaptation to altitude and cold, the divers have to plan for survival in remote areas with sparse medical or rescue facilitics.

Diving procedures necd special consideration since the divers first have to adapt to the low pressures, hypoxemia and reduced physical capabilities at altitude. On diving they are exposed to increasing pressures and on return to surface to the low ambient pressure. For use in diving emergencies we were carrying a monoplace hyperbaric chamber but the divers could be exposed to low pressures while being evacuated by unpressurized helicopters to the hospital at I eh.

To appreciate the changes in diving principles while 